\title{
Afterword: What was Britain? Where is its history?
}

\author{
Tamson Pietsch \\ University of Sydney, Australia
}

\begin{abstract}
This article considers the different ways British history has been located and defined in the last forty years, highlighting in particular the shifting and porous nature of its borders. The article reflects on the disinclination of many contributors in this issue to adopt the label of 'British historian'. It points out that, despite the emergence of transnational history, those historians working in Australia on British sources continue to find themselves pulled between the national imperatives of multiple countries. But both transnational and national historical approaches might be seen as attempts to make sense of human lives and institutions made within systems that work by at once connecting and separating localities. The article concludes by arguing that historians working on British sources in Australia need to claim both labels of 'British' and 'Antipodean'. They need to situate themselves both within the supply chains of trade, labour and governance, family, expertise and belief that stretched across space, and within the various politics that sought to locate and contain them in different locations.
\end{abstract}

What was Britain? Where is its history? These questions were at the heart of J. G. A. Pocock's 1975 plea for a new British history, referred to by several contributors in this special issue. They were also central to the 'new imperial history' that developed in the 1990s and that has stimulated so much recent work on Britain and its empire. And now they find a new set of answers in James Vernon's account of the history of Britain.

Written at diverse political moments, each of these three historiographical departures approached these questions slightly differently. In the wake of the break-up of empire and the United Kingdom's associated entry into Europe, Pocock was writing against a scholarship that saw 'British' history as largely constituted by the actions, institutions and culture of the English. His vision of 'Britain' was an expansive one - reaching out to include the whole 'Atlantic archipelago' of Ireland, Scotland and Wales as well as England and encompassing aspects of the settler societies of Canada, Australia, 
New Zealand and even the United States. 'British history', argued Pocock, lay in this 'British cultural star cluster', made up of plural and conflicting societies, 'in highly dispersed condition' and with its 'central giant' cooled and shrunken. ${ }^{1}$

The new imperial history was taken up in the UK in the context of a contemporary politics that was wrestling with the place of race in multi-ethnic post-imperial Britain. Writing against a view of the British past that separated 'national' from imperial history, and rejecting the dominance of the latter over the former, it argued that British history could not be written with attention to the British Isles alone. Rather, hierarchies of race, gender and class, fashioned across the globe, brought imperial rule deep into British domestic life and politics. Focusing on relationships, networks and circuits of power, scholars such as Antoinette Burton, Catherine Hall, Kathleen Wilson and Mrinlini Sinha placed metropole and periphery within the same analytic field, and argued that the concept of the nation itself needed rethinking. ${ }^{2}$

Now more than a decade later, James Vernon is writing in the context of a new consciousness about global capitalism and its marketised modes of governance as they are played out in a host of social, political and cultural arenas - from the university to austerity measures, from the environment to the digital economy. He sets himself against historiographies that (in the textbooks at least) contain neither 'any sustained account of Britain's economic history, let alone its global footprint' nor 'any organizing narrative or explanatory principle'. ${ }^{3}$ Vernon is also writing against a popular narrative that continues to assert, and even celebrate, Britain's global past. ${ }^{4}$ Focusing on how British history has been shaped by the changing forms of liberal political economy, he makes a case not just for the importance of empire to the constitution of Britain, but also for the role played by much wider global structures, processes and conflicts. Far from making the modern world, Vernon argues, Britain was made by and in it.

${ }^{1}$ J. G. A. Pocock, 'British History: A Plea for a New Subject', Journal of Modern History 47, no. 4 (1975): 621.

${ }^{2}$ See, for example, Antoinette Burton, 'Who Needs the Nation? Interrogating 'British' History', Journal of Historical Sociology, 10, no. 3 (1997): 227-48.

${ }^{3}$ James Vernon in this issue, 26.

${ }^{4}$ I am thinking here of the continuing popularity of imperial histories, exemplified by Niall Fergusson's Empire: The Rise and Demise of the British World Order and the Lessons for Global Power (New York: Basic Books, 2003). 
If Pocock extended British history to include the four nations and the settler colonies, and the new imperial historians broke down the boundaries between its domestic and imperial containers, Vernon here seems to suggest that nation and empire alike, were shaped 'by events, processes and peoples far beyond the Anglosphere'. ${ }^{5}$ All three interventions point to a 'Britain' whose borders are shifting and porous; with a history that can, and indeed must, be written by attending to processes, people and sources that are to be found outside as well as within the British Isles.

It seems odd, then, that given this porousness, so many of the contributors in this issue who work with British sources, are reluctant to adopt the label 'British historian'. Boucher and Fullagar suggest this has much to do with the nation and its continuing salience in Antipodean historiography. But what are the Antipodes? Where is their history? These are not questions that Boucher and Fullagar and their contributors directly address. Yet they are important if we are to speak about what constitutes 'Antipodean' perspectives.

Arguably the production of the nation (albeit as white, democratic, liberal, imperial and largely male) has been a focus of history writing in Australia and New Zealand from its respective beginnings: these were settler societies that were evidently made. Who and what contributed to their making, however, has been open to revision across the generations. Attention to the experiences of workers, women, migrants and indigenous people has forced a rewriting of the old progressive imperial story, with the latter in particular driving the history wars of the 1990s. As Leigh Boucher outlines here, Patrick Wolfe's theorisation of settler colonialism emerged at this time too, when indigenous groups were making claims on national legal systems. Feminist and post-colonial theories were widely influential, and cultural history achieved a prominent place in departments at this same moment. In many ways the four chief lines of inquiry that Boucher and Fullagar hazard as evident in this issue - reformism, history from below, feminist approaches, and postcolonial analyses - reflect its concerns. But this history is one located firmly within these shores: while it allows for influences from outside, it is their adoption and adaption in national contexts that has been the dominant focus of study.

\footnotetext{
${ }^{5}$ Vernon, this issue, 26.
} 
Britain, in particular, has largely disappeared from these stories. The turn to settler colonial studies has sparked a diverse range of work on the cultures and mechanisms of settler rule in various national contexts. But although settler colonialism is understood as a global phenomenon, it effectively nationalises stories once seen as part of a British or imperial narrative. And what this means in New Zealand is evidently very different to what it means in Australia. Some of the best new national histories are turning explicitly to connections abroad, asking questions about the boundaries of 'Australia' and 'New Zealand' and the diverse locations of their respective constructions. ${ }^{6}$ The notion of the 'transnational' may be attractive partly because it offers national scholars a way of talking about the global connections of the past, without casting Australia as colonial. But as Ian Tyrrell suggests, like national readings of the past, these transnational accounts need to guard against projecting backwards our understanding of the post-imperial nation. ${ }^{7}$ Frederick Cooper reminds us that the nation-state is a phenomenon of recent origin and of uncertain future. ${ }^{8}$ Although its actions have frequently had devastating consequences, it has never had a monopoly on rule, with corporations, institutional bodies and trading companies (among others) working alongside, in collaboration and in contest and competition with it, exerting forms of governance across borders as well as organising relations within them. Connections with Britain and its empire directed Australia's global engagements well into the twentieth century. Although it is not a chronology that most 'Antipodean perspectives' have adopted, James Curran and Stuart Ward put the birth of the 'unknown nation' as late as the 1960s and 1970s. ${ }^{9}$

Fixing the categories of 'Britain', 'colony' and 'nation' has been central to the project of national history since its beginnings, but it is manifestly a process that continues into the present, bolstered by the funding regimes and publishing criteria of

\footnotetext{
${ }^{6}$ Marilyn Lake and Henry Reynolds, Drawing the Global Colour Line: White Men's Countries and the International Challenge of Racial Equality (Cambridge: Cambridge University Press, 2008), is perhaps the most obvious, but Sophie Loy-Wilson's writing of Australian history with Chinese sources also comes to mind.

${ }^{7}$ Ian Tyrrell, 'Reflections on the Transnational Turn in United States History: Theory and Practice', Journal of Global History 4 (2009): 461.

${ }^{8}$ See, for example, Frederick Cooper, Colonialism in Question: Theory, Knowledge, History (Berkeley: University of California Press, 2005).

${ }^{9}$ James Curran and Stuart Ward, The Unknown Nation: Australia after Empire (Melbourne: Melbourne University Press, 2010).
} 
nationalised intellectual institutions. For those who use British sources to examine aspects of the past in Australia and New Zealand, it is difficult to escape the gravitational pull of these national imperatives.

But we would do well to remember that since the 1970s 'British' historians in Britain have also been pursuing their own protracted nationalist project(s). Despite the now established position of Atlantic World scholarship, despite the interventions of the new imperial history, and despite the rise of transnational approaches, these are nationalist projects that have remained relatively resistant to arguments about broader understandings of the nation. Indeed, it is against the various insular and triumphant strains of the national story in Britain, that Pocock, the new imperial history, and now Vernon, have in their different ways all been engaged.

This is reflected in the curricula of universities across the country. In English institutions, many first-year survey courses on nineteenth- or twentieth-century 'British' history might give a week to the cultures of empire, just as they give a week to Ireland and a week to gender, but the long-established focus on social, political and (of course) military history remains at their core. Academics tend to gear special subjects at second and third year around their own research interests, and accordingly they zoom in on periods or themes. Informed by the great social history tradition inaugurated by E. P. Thompson and developed by Ross McKibbin (does he count as Antipodean?) and others; or by the cultural historical approaches exemplified by Peter Burke; or the application of poststructuralist theory as expounded by Patrick Joyce, these subjects reflect the richness of British historiography, but their focus tends to remain a largely local one.

At graduate level the division is even more evident. At Oxford and Cambridge, Irish and imperial history are sectioned off from 'British history', with subject streams all of their own, complete with separate seminar series. At the Institute for Historical Research in London there are several seminars devoted to 'modern' British history, but the place of the new imperial history is made evident by its status as just one 
among them. ${ }^{10}$ In the case of Imperial history these seminars have increasingly expanded to take in the new global history, rather than speak back to histories of the nation. In the universities of Scotland, Ireland and to an extent also in Wales, British history has retreated in much the same way as in Australia, with their own national histories asserting a new priority. ${ }^{11}$ These are not, of course, the only angles of view, and new Masters level courses in Birmingham, as well as more established offerings (University College London, Sussex, Royal Holloway University London, and Manchester come to mind), signal wider approaches. But the structure of much British history teaching in Britain does not encourage the making of connections across either the internal or the external borders of the British Isles.

Those working in Australia on British sources thus find themselves pulled between the national imperatives of two countries. (Three including New Zealand, though it is telling that - in this issue at least - New Zealand is a marginal part of our definition of the 'Antipodes'.)

There is a contradiction in this. The rise of national cultural history and settler colonial studies developed at the same moment that new global iterations of liberal governance were reshaping the structures of economic, political and social life across western democracies, unmaking many of the national institutions and industries (banking, trade, monetary policy) that characterised the postwar period. Reforms to the university sector were part of this. In the last 15 years in particular they have entailed the introduction of mechanisms of competition that encourage students, institutions and scholars alike to think of themselves as acting within a global market. The rise of digital access to sources, journal articles, online scholarly communities, cheaper travel and funding opportunities has only worked to re-enforce this. The reluctance of historians in Australia to make claims to 'Antipodean' distinctiveness (even as they are pulled by national imperatives) is perhaps linked to this apparent deterritorialisation of their academic practice. After all, 'Antipodean perspectives' on British history are not to be found only in Australia, and the 'Antipodean

${ }^{10}$ See 'Research seminars at the IHR', Institute of Historical Research, accessed 16 October 2015, http://www.history.ac.uk/events/seminars.

${ }^{11}$ An important exception here is the rich and developing literature on the Scottish experience of empire, exemplified by Tom Divine's Scotland's Empire: The Origins of the Global Diaspora (London: Penguin, 2012). 
perspectives' grouped together in this issue have not been fashioned only on these shores.

As historians we are undoubtedly made by and in the world, yet for all its apparent borderlessness, it remains a world whose scholarly highways enable travel to some places and for some people much more than they do others. In this world we in the 'Antipodes' are relatively privileged. It is our particular connected history (as part of the English-speaking former British empire) that buys us good access to the international universities, overseas students, archives, journals and funding opportunities that are so crucial to the contemporary (neo)liberal intellectual order. We are manifestly not free-floating agents, writing disembodied, into a flat and undifferentiated scholarly market that is characterised by so many equally competing 'global' universities. Rather, we are both conditioned and enabled by thick networks of connection, and by variously resourced and located institutions in polities with particular imperatives, We work in the midst of specific currencies of legitimacy and we are fashioned by distinct intellectual and economic geographies that massively advantage us in the new transnational politics of global higher education.

A quick overview of the careers of the contributors to this issue gives a good sense of where these geographies might lie - at least for those whose work touches on the British past in Australia. Trained between the mid-1970s and mid-1990s, Swain, May and Blaazer completed their historical studies in Australia (at the University of Melbourne and La Trobe University) and have subsequently spent their careers here. They reflect the localisation of the structures of knowledge in this period and the nationalisation of academic careers across a whole range of disciplines. By contrast, the trajectories of McKenzie, Greenhalgh and Evans point to the enduring power of older routes of travel. ${ }^{12}$ Before coming to Australia, McKenzie and Greenhalgh studied first in Cape Town and Auckland respectively, before proceeding to Oxford for their doctoral studies, while Evans completed her undergraduate studies in Edinburgh, and her doctoral and postdoctoral work in London. (And I should add myself in here too: I studied first in Adelaide, then at Oxford, and taught at Brunel

\footnotetext{
${ }^{12}$ Tamson Pietsch, Empire of Scholars: Universities, Networks and the British Academic World, 18501939 (Manchester: Manchester University Press, 2013).
} 
University in London, before coming back to Sydney thanks to the Australian Research Council.) Kate Fullagar's shift from the Australian National University to Berkeley and back to Sydney and Macquarie reflects a path through US institutions increasingly being travelled by Australian graduates, as markers of legitimacy and the direction of networks change. Boucher too, who studied at the University of Melbourne in the 2000s before undertaking postdoctoral work in the UK and returning to Macquarie in Sydney, is indicative of a generation of locally-trained scholars who now compete globally for postdoctoral positions.

Of course, these scholars work in archives abroad, read histories produced in a variety of national contexts, attend international conferences, and engage with theory that circulates across language boundaries. But as I have suggested, the ways they do so follow certain patterns, and map out distinct material and intellectual geographies that are shaped by historical connection, language, intellectual networks and genealogies, institutional support, the beneficence of funding bodies (especially the ARC) and the limits of personal lives. It is within these distinct geographies that 'Antipodean perspectives' on British history are produced.

These are 'geographies' that have been fashioned by Australia's particular experience of globalised capitalism. Another way of looking at the different pieces brought together in this special issue might be to see them as offering perspectives on British histories that are deeply informed by the enactment of these histories in the Antipodes. Made by the tendrils of cross-border capital, the routes of imperial and transnational migration, the regimes of land, labour, trade and consumption, as well as by local efforts to resist, capture and direct these forces, this history played out in Australia (as in other contexts) in ways that were at once specific and extended. In their scattered focus, the articles in this issue together reflect this. They each take up aspects of this situated global story - its violent underpinnings and logic of dispossession (Boucher), its social reform movements (Swain, Evans, Greenhalgh), family networks and individual stories (May), monetarist policy (Blaazer), its fragility of rule (Fullagar, McKenzie) and - perhaps most importantly - its dispersal, displacement and erasure of connected processes and histories (all). 
This latter task particularly, as so many of those who have been influenced by the transnational turn have argued, is central to understanding the neo-liberal context of our own intellectual production and the way it influences our work. It was no accident that Pocock spent so long in New Zealand (indeed he himself points to its significance in his work) $)^{13}$ or that Catherine Hall worked in multi-ethnic Birmingham and was married to a pre-eminent cultural theorist, the Jamaican-born Stuart Hall. Neither is it a coincidence that James Vernon's account of the global formation of Britain is written from California in the mid-2010s when marketised policies are exerting new pressures upon social and political life on both sides of the Atlantic, including universities.

That Pocock's, Hall's and Vernon's porous approaches to British history should have emerged alongside national articulations with their more located, insular and granular concerns, is not surprising. Both transnational and national approaches, after all, might be seen as attempts to make sense of human lives and institutions made within systems that work by at once connecting and separating localities. As historians working on British sources in the Antipodes (or anywhere else for that matter) our task might be, then, to claim both labels of 'British' and 'Antipodean' and speak into both national historical conversations. It might be to situate ourselves within the supply chains of trade, labour and governance, family, expertise and belief that stretched across space, and within the particular politics of localisation that sought to locate and contain them in various contexts. These not only shaped the lives of our historical subjects, they also (if in a somewhat different guise) continue to shape our own.

\section{About the author}

Tamson Pietsch is an ARC Discovery Early Career Researcher in History at the University of Sydney. She is the author of Empire of Scholars: Universities, Networks and the British Academic World, 1850-1939 (Manchester University Press: 2013), and various articles on the history of universities, maritime travel, and modern and imperial Britain.

Correspondence to: tamson.pietsch@sydney.edu.au

\footnotetext{
${ }^{13}$ Pocock, 'British History: A Plea for a New Subject', 617.
} 